\title{
Using Fairy Tales and Children's Literature in the Math Classroom: Helping All Students Become Einstein's in a STEM World
}

\author{
Joseph M. Furner \\ Florida Atlantic University, Jupiter, FL, USA \\ Email: jfurner@fau.edu
}

\begin{abstract}
Getting young people excited about mathematics is critical in our high-tech world. Teachers today need to encourage students to be confident in their ability to solve problems, to think and use their imaginations, to understand mathematical concepts, to be creative, and see math as a human endeavor. The author believes that as students feel less anxious about, and more confident in their abilities to do math their performance will improve. Math anxiety has become a growing concern in the United States as well as in many other countries around the globe. Educators need to address this alarming problem and work toward developing mathematically confident young people for a world where Science, Technology, Engineering, and Mathematics (STEM) fields dominate the globe. Using children's literature and fairy tales to teach math may help in addressing the improvement of attitudes toward mathematics and help students to be more creative and imaginative in a world with endless possibilities and with advancing technologies. Bibliotherapy is also discussed.
\end{abstract}

Keywords: Children's literature, STEM, math anxiety, fostering intelligence, imagination, creativity, bibliotherapy

\section{Introduction}

"If you want your children to be intelligent, read them fairy tales. If you want them to be more intelligent, read them more fairy tales."

\section{- Albert Einstein 1879-1955}

In the fairy tale Sir Cumference and the Dragon of Pi, a Math Adventure (Neuschwander, 2004), the son Radius (the name is referred to but not described in math terms) saves his father's life, Sir Cumference, after accidentally turning him into a fire breathing dragon. Of course, a math formula is the reason for the solution. Did you know Sir Cumference named Pi in this story? Did you know this story tells how the math formula for $\Pi$ was discovered? This is a fictional story but the author's purpose is achieved when children remember this math lesson and what Pi means.

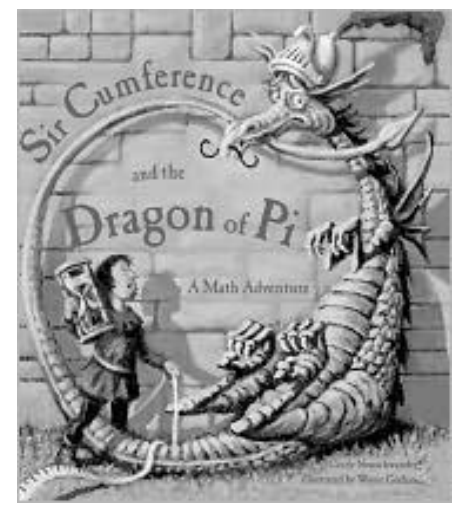

Book Cover Image 


\section{$2 \quad$ Building Math Confidence for a STEM World}

Today we live in an age of advancing technologies that are constantly changing. Children need to be literate as well as be very good at mathematics and problem solving in order to compete in a global society. A youngster's lack of confidence and ability to do mathematics may impact his/her entire life forever both in all decisions they make on a daily basis as well as future career choices. Teachers today must be equipped to reach all children and develop their confidence and ability to do mathematics. Teachers must check to see that all children have positive attitudes and dispositions toward math (NCTM, 1989). As Boaler (2008) points out, it is critical to ensure our young people are confident and well prepared in mathematics if they are going to compete for such high-tech jobs today and in the future. Today, the United States is working to lead more young people into the fields of Science, Technology, Engineering, and Mathematics (STEM) so we as a country can better compete globally. If we are to build math confidence in our students, math teachers need to address the issue of math anxiety which often manifests itself as hesitancy or learned helplessness in observed math achievement. Burns (1998) and Jackson \& Leffingwell (1999) show that Americans do not like mathematics. Burns contends that two-thirds of Americans loathe math and Jackson \& Leffingwell found that only about $7 \%$ of Americans reported having positive experiences while taking math classes at the Kindergarten through college levels. This is alarming in our information age where mathematics plays such a critical role. Sparks (2011) feels that as the STEM fields become more important for our students to study, our schools and teachers need to do more to address math anxiety so that our students are confident to study areas related to STEM. With the NCTM Standards pushing for more communications in mathematics (NCTM, 1989 \& 2000) and also the push to incorporate literature in the teaching of mathematics, teachers are now able to make better connections to mathematics and students' lives. Today there are literally thousands of children's literature books out there to teach mathematics, this article will share several of them, advocating their use (See Appendix and A and B for an extensive list of math related literature).

\section{$3 \quad$ Using Fairy Tales and Children's Literature to Teach Math}

Within the past decade or two children's and adolescent literature has been recognized as a means to teaching mathematics concepts to students through the use of stories to make mathematics ideas relevant and meaningful. Literature can also be used as a form of therapy (bibliotherapy) to reach students who may be frustrated with being taunted or teased for excelling in mathematics of for having math anxiety. Rozalski, Stewart and Miller (2010) have found that using carefully selected thematic books; teachers can use literature to reach young people who are experiencing difficult situations.

Teachers can use children's literature to reach a child in a non-threatening way by reading literature that can help to teach math concepts and really connect to the mathematical understanding of the learner and at the same time not intimidate, threaten, or turn-off a child to mathematics like some traditional approaches may have in the past. Children's and adolescent literature can be a beneficial way of teaching mathematics (See Appendix A and B).

Benefits of Using Literature in Mathematics Instruction

- Math concepts are taught in the context of a story

- Incorporates integrated studies with reading, writing, speaking, listening, etc.

- Develops mathematical thinking

- Prevents math anxiety and creates a less math anxious classroom environment

- Allows for a variety of responses

- Makes historical, cultural, and practical applications and connections

- May allow for the use of manipulatives as it relates to the story

- The teacher can assess a child's understanding by reading/questioning

- Today there is a range of books to use in teaching most math concepts K-8

- May lead to problem solving and active involvement from the context of the story

- Provides a shared experience for students and the teacher

Teachers can address the NCTM's "Communication Standard" by incorporating literature in the teaching of mathematics as well as by having students discuss math from the stories and write about 
such concepts in mathematics to demonstrate their understanding of math concepts as well as their feelings toward math. Griffiths \& Clyne (1991) in their book, Books you can count on: Linking mathematics and literature, illustrate wonderfully many examples of how to connect children's literature into a math lesson. Included below is a sample of some suggested activities tying literature into the teaching of mathematics. It is important to mention a distinction between using literature in the teaching of mathematics, teachers may use literature to introduce, teach, reinforce, and make important connection to many math concepts through the use of story books that hold mathematics themes. There are also books that may be used to assist students with helping them come to terms with things like fear of mathematics for example, the book, Math Curse (Scieszka \& Smith, 1995), or the book, Counting on Frank (Clement, 1991), which can be used to help gifted math students to accept and respect their giftedness with mathematics (Furner and Kenney, 2011).

\section{$4 \quad$ Math Bibliotherapy}

Affective factors play such an important role in learning (McLeod, 1992) and teachers need practical classroom strategies to address the feelings of their students suffering from mathematics anxiety. Teachers need to create supportive environments in which their students feel comfortable expressing how they are feeling about their mathematical experiences. One approach in helping young people express themselves comfortably is through bibliotherapy. Bibliotherapy is reading of selected literature to produce affective change and to promote personality growth and development (Abdullah, 2002; Betzalel \& Shechtman, 2010; Doll \& Doll, 1997; Forgan, 2002, 2003; Furner, 2004; Jeon, 1992; Heath, Sheen, Leavy, Young \& Money, 2005; Jack \& Ronan, 2008; Lenkowsky, 1987; Reis \& Renzulli, 2004; Rozalski, Stewart \& Miller, 2010; Sridhar \& Vaughn, 2000; Sullivan \& Strang, 2003). Bibliotherapy can be used as an attempt to help young people understand themselves and cope with problems by providing literature relevant to their personal situations and developmental needs (Betzalel \& Shechtman, 2010). Hébert and Kent (2000) advocate the use of young adult literature for gifted teenagers to address social and emotional concerns. Teachers using this approach hold a fundamental belief that reading will influence thinking and behavior, and that through guided discussions selected readings can be focused on specific needs of students as well. Reading children's literature, fairy tales, and stories while teaching math concepts can allow students to invoke more creativity and employ their imaginations further while making important mathematical connections to their understanding.

The bibliotherapy process is fairly easy to understand and implement. The therapeutic experience while reading a book happens to us each time we pick up a good book and say, 'This character is very much like me. I can relate to this person.' This interaction is known as identification, and the more we have in common with people we meet in our reading, the closer will be the identification process. That identification produces a sense of tension relief, or 'catharsis,' an emotional feeling that tells us we are not alone in facing our problems. As we enjoy the book, we learn vicariously through the characters in the book. We gain new ways of looking at troublesome issues we face and insight evolves. With this new insight, changed behavior may occur as real life situations similar to those experienced in the books are confronted (Furner, 2004). The three most recognized stages of bibliotherapy are identifications, catharsis, and insight (Forgan, 2002; Halsted, 1994; Jack \& Ronan, 2008); however, another less mentioned in the literature yet especially interesting for teachers working with mathematics anxious students, is the concept of universalization (Slavson, 1950), or the recognition that our problems are not unique. Through universalization we realize that we, as sensitive individuals, 'are in this together.' Thatcher and Fletcher (2008) have found that not all teachers realize or see the value in using literature or bibliotherapy for neither addressing students' problems nor how to use such a process. Hopefully this article helps to address this.

Books can help teachers guide the emotional development of their students' far more than intellectual discussion because stories directly affect human emotions (Forgan, 2002, 2003; Furner, 2004; Rozalski, Stewart \& Miller, 2010). A skillful author can help young people connect with others who have similar problems. If books or short stories can touch young people emotionally, they may be much more receptive to ideas presented by the author than if they are presented to them in a lecture by a concerned teacher. Students who are unable to talk about their anxieties often can identify with characters in books strongly enough to experience the catharsis and acquire some important insights 
(Halsted, 1994; Heath, Moulton, Dyches, Prater \& Brown, 2011).

For bibliotherapy to be successful, a meaningful follow-up discussion is required (Forgan, 2002; Furner, 2004). To simply read a good book with an entire class is not bibliotherapy. It is very important that young people not only read books, but also become involved in discussions, counseling and follow-up techniques such as role-playing, creative problem solving, relaxation with music, art activities and journal writing (Furner, 2004; Forgan, 2002, 2003; Hébert, 1991, 1995; Hébert \& Furner, 1997). When presented in this way, bibliotherapy can be enjoyable while providing a time for solid introspection for young people.

It is important that sensitive mathematics teachers' help students recognize that their abilities may differ from their peers, acknowledge that they may also have areas of weakness and assist them in developing self-esteem by become satisfied with who they are as individuals (Ableser, 2008). Teachers using bibliotherapy may be successful in doing so by making connections to the students' attitudes and feelings with the characters in story books (Regan \& Page, 2008). Leininger, Dyches, Prater and Heath (2010), Burke (2009), and Kurtts and Gavigan (2008) have all found that there are a wide range of literature and picture books useful in conducting bibliotherapy to address a wide range of conditions and societal factors impacting young people today. The bottom line here is that using fairy tales or literature to teach mathematics can be beneficial for student in learning mathematics concepts in a more meaningful way, making important connections while allowing our young people to employ some creativity and imagination to the learning situation. Too, the use of bibliotherapy is also beneficial in that it can help some students in class who might either struggle with fears or anxiety about math or even the peer-pressure of being mathematically gifted and considered a geek or nerd.

\section{Some Possible Math Activities for Teachers to Try Using Literature}

1. "Alphabet Snoop" is an activity used as a project for the Palm Beach County Math Fair by a second grade classes. The children predicted which letter of the alphabet would occur most frequently in their reading books. The activity included tallying with tally marks, individual graphing, class graphing, and the use of calculators. It was very exciting and rewarding for the class as it incorporated children's literature and actual mathematics in a non-threatening way.

At the intermediate grade levels, students can also connect math and language concepts in a similar fashion. There are a series of books on the parts of speech by Ruth Heller that could be used to stimulate student interest as they relate to different parts of speech. These books could be used to identify different types of words and understanding their use, an important approach for English Language Learners (ELL) students. Some math skills that can be applied are:

- Assembling information and choosing an appropriate way to record and display.

- Averaging the usage of words and finding percentages of kinds of words used in different types of writing.

- Finding patterns in various forms of writing and expressing them in mathematical terms.

- Developing calculator skills when analyzing information.

These are a few of many ideas that you can develop.

2. Another great idea to connect math and literature in the classroom is by using The Grandfather Tang's Story, a Chinese folktale; this book uses tangrams to tell a whimsical story of meeting many creatures during the characters odyssey. This story can be read and used with transparencies and student activity pages geared to the appropriate grade levels to make this a participatory activity. The younger children can use pictures with outlined pieces in the drawing, while the older ones had only the basic outline and had to fill it in with the tangrams to make the animal mentioned on each page of the story. Children can also come up to the projector to work with the tangram pieces. It can be a very successful lesson at all grade levels. The use of literature to develop math concepts can go a long way in relieving children's math anxiety.

3. Teachers may use Shel Silverstien's poem, Smart, while teaching a unit on money. The poem starts out with a young boy receiving a one dollar bill from his dad because he is "his smartest son" and he goes through a series of trades and transactions to receive other coins. He feels that each time he trades and receives more coins he has more than one. For example, swapping the one dollar bill for two shiny 
quarters "cause two is more than one. After reading this poem to children, a teacher may use a journal writing prompt activity from the book, Write Starts: 101 Writing prompts for math, by McIntosh \& Draper (1997), to have the students write about and then discuss "What the error is in the story (problem)." Teachers may use many of the prompts in this book for follow-up of different children's literature. How is math used in your favorite sport? Maybe be a great writing prompt after students read the book, Sports Math Mania, by Hopping and Egan (1996). Teachers could use the prompt: One sign of a good problem solver is.... After reading the book Betcha!, by Murphy and Schindler (1997).

4. The use of bibliotherapy has been a recognized means for reducing/overcoming math anxiety. Teachers can read stories to children, like the book, Math Curse and A Gebra Named Al, and then have student share how the characters relate to them and their own bad experiences with math. This can be a catharsis or therapeutic for children who may feel as the character did and help them recognize they are not the only ones that feel this way. Teachers may too encourage students to discuss and write about their own experiences with math and perhaps direct them to write their very own math autobiography (Kitchens, 1995). Teachers can just use literature to introduce, teach, or reinforce math concepts and then extend their students' understanding allowing the students to discuss and write about their understanding through various activities. It is critical in this day and age that we reach all students and if literature can be a means to reach children and turn them on to mathematics then teachers need to incorporate this best practice!

5. A Cloak for the Dreamer, by Friedman and Howard (1994) is a wonderful story to read to students to teach about two-dimensional geometry, spatial sense, and tessellations. Today there is almost an endless array of children's literature for teaching mathematics concepts to cover almost any NCTM and Sunshine State Standard Strand in mathematics from Number Sense, Measurement, Geometry, Algebraic Thinking, and Data Analysis, etc. A Cloak for the Dreamer tells a story of a tailor being commissioned by the Archduke to design and sow three new cloaks for himself and three dresses for his wife. The Archduke requires the cloaks to be very colorful and also use shapes so that there are no gaps or overlaps so that he will not be cold and that no material will be wasted. The tailor has his three sons help him out with this task. This book explores tessellations. It can lead to a nice activity with manipulatives like pattern blocks where children can discover which shapes tessellate. Children's literature books like this are wonderful to read as a shared experience with children as they teach mathematical concepts within the context of a story making the learning of mathematics more meaningful to the learner.

Geist (2010) feels that negative attitudes toward mathematics and what has come to be known as "math anxiety" are serious obstacles for children in all levels of schooling today. In his paper, the literature is reviewed and critically assessed in regards to the roots of math anxiety and its especially detrimental effect on children in "at-risk" populations such as, special education, low socioeconomic status, and females, he feels that an anti-anxiety curriculum is critical in building students' confidence when working with mathematics. We need to use best practices like incorporating children's literature in the teaching of mathematics to be sure to turn students on to math.

\section{Summary}

Albert Einstein said, "Everybody is a genius. But if you judge a fish by its ability to climb a tree, it will live its whole life believing that it is stupid." As educators we need to seek every which way to reach all types of students, turning them on to math and making them feel confident to do math and solve any problem, and also to have them use their creativity and imagination in the learning process. In today's times of increasing technology and with more of a push to better prepare more young people for the STEM fields, children must be confident in their ability to do mathematics. With recent statistics showing students poor attitudes or declining scores in math as they increase in age for example from the Third International Mathematics and Science Study (TIMSS) (Schmidt, 1998) and other researchers like Burns (1998) and Jackson \& Leffingwell (1999). Today, teachers can address the issue of math anxiety in their students by using children's literature and writing to help in reducing such anxiety by using books as a form of what is called bibliotherapy. Teachers can also incorporate children's literature to help in preventing math anxiety from occurring by using such books in a shared setting with students making such connections to mathematics in more meaningful ways along with incorporating writing, 
discussion, and the use of manipulatives as they relate to the story in the children's literature book.

Teachers can do many things mentioned in this article in their own classrooms to help prevent and reduce math anxiety. As a society, we must work together to extinguish this discomfort that our kids are having toward mathematics. It is important that our students feel confident in their ability to do mathematics in an age that relies so heavily on problem solving, technology, science, and mathematics. It really is a teachers' obligation to see that their students value and feel confident in their ability to do math, because ultimately a child's life: all decisions they will make and careers choices may be determined based on their disposition toward mathematics. As teachers we must make the difference in our students' attitudes toward math! Using children's literature can help make better connections in math. Today it is important that we hear more students say, "Math is my favorite subject," "I am a good problem solver," "I am great at math!" or "I want to be an inventor or scientist!" Einstein said, "I am enough of an artist to draw freely upon my imagination. Imagination is more important than knowledge. Knowledge is limited. Imagination encircles the world." When teachers use fairy tales and children's literature in their classroom to teach math, they are allowing for creativity, imagination, and making connections for students better preparing them for a world which is ever advancing mathematically and technologically. We need to prepare our students for such a world.

\section{References}

1. Abdullah, M.H. (2002). Bibliotherapy. ERIC Digest. Bloomington, IN: ERIC Clearinghouse on Reading, English, and Communication. (ERIC Document Reproduction Service No. ED470712). Available from http://www.eric.ed.gov/PDFS/ED470712.pdf

2. Ableser, J. (2008). Authentic literacy experiences to teach and support young children during stressful times. Young Children, 63, 74-79.

3. Betzalel, N., \& Shechtman, Z. (2010). Bibliotherapy treatment for children with adjustment difficulties: A comparison of affective and cognitive bibliotherapy. Journal of Creativity in Mental Health, 5(4), 426-439. http://dx.doi.org/10.1080/15401383.2010.527816

4. Boaler, J. (2008). What's math got to do with it? Helping children learn to love their least favorite subject--and why it's important for America. New York, NY: Penguin Group (USA) Inc.

5. Burke, A. (2009). Gifted and grieving: Why it is critical to offer differential support to gifted kids during times of loss. Gifted Child Today, 32(4), 30-37.

6. Burns, M. (1998). Math: Facing an American phobia. Sausalito, CA: Math Solutions Publications.

7. Clement, R. (1991). Counting on Frank. Milwaukee, WI: Gareth Stevens Publishing.

8. Doll, B., \& Doll, C. (1997). Bibliotherapy with young people: Librarians and mental health professionals working together. Englewood, CO: Libraries Unlimited.

9. Forgan, J.W. (2002). Using bibliotherapy to teach problem solving. Intervention in School and Clinic, 38, 75-82. http://dx.doi.org/10.1177/10534512020380020201

10.Forgan, J.W. (2003). Teaching problem solving through children's literature. Westport, CT: Teacher Ideas Press Libraries Unlimited.

11.Friedman, A., \& Howard. K. (1994). A cloak for the dreamer. New York: Scholastic.

12.Furner, J.M. (2004). Using bibliotherapy to overcome math anxiety. Academic Exchange Quarterly, 8, $209-213$.

13.Furner, J.M., \& Kenney, C. (2011). Counting on Frank: Using bibliotherapy in mathematics teaching to prevent de-geniusing. Pythagoras, 32(2), Art. \#133, 7 pages. http://dx.doi.org/10.4102/pythagoras.v32i2.133.

14.Geist, E. (2010). The anti-anxiety curriculum: Combating math anxiety in the classroom, Journal of Instructional Psychology, 37(1), p24-31.

15.Griffiths, R., \& Clyne, M. (1991). Books you can count on: Linking mathematics and literature. Portsmouth, NH: Heinemann.

16. Halsted, J.W. (1994). Some of my best friends are books: Guiding gifted readers from pre-school to high schools. Dayton, OH: Ohio Psychology Press.

17.Heath, M.A., Moulton, E., Dyches, T.T., Prater, M.A., \& Brown, A. (2011). Strengthening elementary school bully prevention with bibliotherapy. Communiqué Online, 39(8). Available from http://www.nasponline.org/publications/cq/39/8/strengthening-bully-prevention.aspx 
18.Heath, M.A., Sheen, D., Leavy, D., Young, E., \& Money, K. (2005). Bibliotherapy: A resource to facilitate emotional healing and growth. School Psychology International, 26(5), 563-580. http://dx.doi.org/10.1177/0143034305060792

19.Hébert, T.P. (1991). Meeting the affective needs of bright boys through bibliotherapy. Roeper Review, 13(4), 207-212. http://dx.doi.org/10.1080/02783199109553360

20.Hébert, T.P. (1995). Using biography to counsel gifted young men. The Journal of Secondary Gifted Education, 6, 208-219.

21.Hébert, T.P., \& Kent, R. (2000). Nurturing social and emotional development in gifted teenagers through young adult literature. Roeper Review, 22, 167-171. http://dx.doi.org/10.1080/02783190009554027

22.Hébert, T.P., \& Furner, J.M. (1997). Helping high ability students overcome math anxiety through bibliotherapy. The Journal of Secondary Gifted Education, 4, 164-178.

23.Hopping, L. J., \& Egan, C. (1996). Sports math mania: Cool stats and number facts. New York: Sports illustrated for Kids, a division of Time, Inc.

24.Isdell, W. (1993). A Gebra named Al. Minneapolis, MN: Free Spirit Publishing Inc.

25.Jack, S.J., \& Ronan, K.R. (2008). Bibliotherapy: Practice and research. School Psychology International, 29, 161-182. http://dx.doi.org/10.1177/0143034308090058

26.Jackson, C. D., \& Leffingwell, R. J (1999). The Role of Instructor in Creating Math Anxiety in Students from Kindergarten through College. Mathematics Teacher, 92(7), 583-586.

27.Jeon, K., (1992). Bibliotherapy for gifted children. Gifted Child Today, 15, 16-19.

28.Kitchens, A, N. (1995). Defecting math anxiety. Chicago, IL: Richard D. Irwin, Inc.

29.Kurtts, S.A., \& Gavigan, K.W. (2008). Understanding (dis)abilities through children's literature. Education Libraries, 31(1), 23-31.

30.Leininger, M., Dyches, T.T., Prater, M.A., \& Heath, M.A. (2010). Newbery award winning books 1975-2009: How do they portray disabilities? Education and Training in Autism and Developmental Disabilities, 45(4), $583-596$.

31.Lenkowsky, R.S. (1987). Bibliotherapy: A review and analysis of the literature. The Journal of Special Education, 21, 123-132. http://dx.doi.org/10.1177/002246698702100211

32.McIntosh, M. E., \& Draper, R. J. (1997). Write Starts: 101 Writing prompts for math. White Plains, NY: Dale Seymour Publications.

33.McLeod, D.B. (1992). Research on affect in mathematics education: A reconceptualization. In D.A. Grouws (Ed.), Handbook of research on mathematics teaching and learning (pp. 575-596). New York, NY: Macmillan.

34.Murphy, S. J., \& Schindler, S.D. (1997). Betcha! New York: Scholastic.

35.National Council of Teachers of Mathematics. (2000). Principles and standards for school mathematics. Reston, VA: NCTM.

36.National Council of Teachers of Mathematics. (1989). Curriculum and evaluation standards for school mathematics. Reston, VA: NCTM.

37.Regan, K., \& Page, P. (2008). "Character" building: Using literature to connect with youth. Reclaiming Children and Youth, 16, 37-43.

38.Reis, S.M., \& Renzulli, J.S. (2004). Current research on the social and emotional development of gifted and talented students: Good news and future possibilities. Psychology in the Schools, 41, 119-130. http://dx.doi.org/10.1002/pits.10144

39.Rozalski, M., Stewart, A., \& Miller, J. (2010). Bibliotherapy: Helping children cope with life's challenges. Kappa Delta Pi Record, 47, 33-37.

40.Schmidt, W. H. (1998). Changing mathematics in the U.S.: policy implications from the third international mathematics and science study. Presentation at the 76th Annual meeting of the National Council of Teachers of Mathematics, Washington, D.C., April 3, 1998.

41.Scieszka, J., \& Smith, L. (1995). Math Curse. NY, NY: Viking Press.

42.Slavson, S. R. (1950). Analytic group psychotherapy with children, adolescents, and adults. New York, NY: Columbia University Press.

43.Sparks, S. D. (2011). Math anxiety explored in studies, Education Week, 30(31) p1.

44.Sullivan, A.K., \& Strang, H.R. (2003). Bibliotherpy in the classroom: Using literature to promote the development of emotional intelligence. Childhood Education, 79, 74-80. 
45.Sridhar, D., \& Vaughn, S. (2000). Bibliotherapy for all: Enhancing reading comprehension, self-concept, and behavior. Teaching Exceptional Children, 33, 74-82.

46.Thatcher, K., \& Fletcher, K. (2008). Professionals' perceptions of the role of literacy in early intervention services. Psychology in the Schools, 45(7), 600-608. http://dx.doi.org/10.1002/pits.20312

\section{Appendix A}

Dear Teacher Website: Children's Books with Mathematics Themes Website at: http://www.dearteacher.com/math-books

\section{Appendix B}

A List of Children's Literature/Fairytales for Teaching Mathematics by Math Strand

\section{Children's Literature in the Mathematics Classroom}

\section{Number Sense, Concepts and Operations}

1. Murphy, S.J., Betcha!. Scholastic, Inc. New York. 1997. Teaches number sense through estimation.

2. McGrath, Barbara B., More M \& M's Math. Charlesbridge Publications. 1998. Uses M \& M candies to teach students counting and basic math operations.

3. Murphy, S., Ready, Set, Hop! . HarpersCollins Children's Books, New York. 1996. Teaches counting skills and what operations should be used.

4. Higdon, P. Math Minders: Fractions and Decimals. Grade 5. Frank Schaffer Publications, Inc. California. 1998. Covers fractions and decimals.

5. Snelson, K. The Superb Number 7: A Birthday Number Book. Andrews McMeel Publishing. 1997. The title covers it.

6. Horenstein, H. How are Sneakers Made? Simon \& Schuster Books for Young Readers. New York. 1993. Shows how numbers relate to something all children are familiar with, sneakers.

7. 9Hutchings, A. and Hutchings, R. The Gummy Candy Counting Book. Scholastic Inc. New York. 1997. Teaches counting and adding skills.

8. Radzinski, K. The Twelve Cats of Christmas. Chronicle Books. 1992. Counting skills.

9. Schwartz, D.M. How Much is a Million? Scholastic Inc. New York. 1985. Teaches students about the concept of a million using comparisons. Helps students conceptualize large numbers.

10.Demi. One Grain of Rice: A Mathematical Folktale. Scholastic Inc. 1997.Teaches students about the effects of doubling numbers.

11.Appelt, K. Bat Jamboree. Scholastic Inc. New York. 1996. Teaches about numbers and counting.

12. Choraro, K. Number One Number Fun. Scholastic Inc. New York. 1996. Counting skills.

13.Long, L., Ph.D. Domino Addition. Scholastic Inc. New York. 1996. Teaches number sense and addition with dominoes.

14.McGrath, B. B. The M \& M's Counting Book. Charlesbridge Publishing. MA. 1994. Teaches numbers 1 - 12.

15. Charles, O. How Does Soda Get Into the Bottle? Silver Burdett Press. New Jersey. 1988. Teaches about sequences and steps in a process.

16.Rocklin, J. The Case of the Missing Birthday Party. Scholastic Inc. New York. 1996. Teaches about place value.

17.Carle, E. The Very Hungry Caterpillar. Scholastic Inc. New York. 1987. Counting skills for the very young.

18.Shasha, M. Night of the Moonjellies. Simon \& Schuster Books for Young Readers. New York. 1992. Relates numbers to everyday life.

19.Rocklin, J. One Hungry Cat. Scholastic Inc. New York. 1997. Teaches number sense and division.

20.Leedy, L. Mission: Addition. Scholastic Inc. NY 1997. Teaches addition skills.

21.Pinczes, E. A Remainder of One. Scholastic Inc. NY. 1995. Illustrates division operations and concept of remainders.

22.Cristaldi, K. Even Steven and Odd Todd. Scholastic Inc. NY. 1996. Covers odd and even numbers.

23.Murphy, S. Just Enough Carrots. Scholastic Inc. NY. 1997. Teaches comparison of amounts. 
24.Moore, I. Six-Dinner Sid. Aladdin Paperbacks. NY. 1991. Teaches numbers.

25.Murphy, S. Divide and Ride. Scholastic Inc. NY. 1997. Teaches division skills.

26.Neuschwander, C. Amanda Bean's Amazing Dream: A Mathematical Story. Scholastic Inc. NY. 1998. Teaches multiplication.

27.Merriam, E. 12 Ways to Get to 11. Scholastic Inc. NY. 1993. Addition and counting concepts.

28.Fun With Numbers. Golden Books Workbook. Teaches numbers and simple counting skills.

29.Mazer, A. The Salamander Room. Dragonfly Books. U.S. 1991. Teaches number sense.

\section{Geometry and Spatial Sense}

1. Ryan, S. MYSTIFYING MATH PUZZLES. Scholastic Inc. NY. 1996. Teaches spatial sense through puzzles and mazes.

2. Escher, M.C. WORKS OF ART. Random House Publishing, Inc. New Jersey. 1994. Illustrates geometric and mathematical concepts through wacky graphics.

3. Glass, J. Ph.D. THE FLY ON THE CEILING: A MATH MYTH. Scholastic Inc. NY. 1998. Uses humor and history to teach about the Cartesian Coordinate System.

4. INTERMEDIATE GEOBOARD ACTIVITY BOOK. (GRADES 4-6). Learning Resources. 1990. Gives teachers many examples of how to use geoboards while teaching geometric concepts.

5. TANGRAM PATTERNS. Creative Publications. California. 1977. Teaches spatial sense and geometry by using geometric shapes to form pictures.

6. Burns, M. SPAGHETTI AND MEATBAllS FOR ALL? A MATHEMATICAL STORY. Scholastic Inc. NY. 1997. Teaches concepts of area and perimeter in a real-world context.

7. Neuschwander, C. SIR CUMFERENCE AND THE FIRST ROUND TABLE: A MATH ADVENTURE. Scholastic Inc. NY. 1997. Teaches concepts involved with the measurement of a circle.

8. Millard, A. PYRAMIDS. Scholastic Inc. NY. 1996. Information about the construction of pyramids and the geometric concepts involved.

9. Schreiber, A. SLOWER THAN A SNAIL. Scholastic Inc. NY. 1995. Teaches spatial sense through comparisons.

10.Maccarone, G. THE SILLY STORY OF GOLDIE LOCKS AND THE THREE SQUARES. Scholastic Inc. NY. 1996. Teaches about geometric shapes.

11.Ayture-Scheele, Z. THE GREAT ORIGAMI BOOK. Sterling Publishing Co., Inc. NY. 1987. Teaches geometric concepts and spatial sense through ancient Japanese art of paperfolding.

12.Friedman, A. A CLOAK FOR THE DREAMER. Scholastic Inc. NY. 1994. Teaches geometric concepts in a reallife context.

13.Murphy, S. GIVE ME HALF? HarperCollins Publishers. NY. 1996. Teaches fractions using shapes and sizes.

14.Pallotta, J. THE HERSHEY'S MILK CHOCOLATE FRACTIONS BOOK. Scholastic Inc. NY. 1999. Uses Hershey bar pictures to illustrate fractions.

15.Irvin, B. Ph.D. GEOMETRY AND FRACTIONS WITH PATTERN BLOCKS. Learning Resources, Inc. 1995. Uses hexagon shapes to teach geometry and fractions.

16.Leedy, L. FRACTION ACTION. The Trumpet Club, Inc. 1994. Uses common shapes to teach concepts about fractions.

17.DECIMAL SQUARES: STEP-BY-STEP TEACHER'S GUIDE. Scott Resources, Inc. 1992. Illustrates how to use decimal square manipulatives to teach about decimals.

18.Kleinhenz, S. M. MORE FOR ME! Scholastic Inc. NY. 1997. Helps develop spatial sense.

19.Stamper, J.B. TIC-TAC-TOE: THREE IN A ROW. Scholastic Inc. NY. 1998. Uses the game of tic-tac-toe to teach children to think spatially.

20.Murphy, S. A PAIR OF SOCKS. Scholastic Inc. NY. 1996. Teaches spatial concepts.

21.Bayha, B. and Brut, K. PATTERN BLOCKS ACTIVITIES. Dale-Seymour Publications. 1985. Uses pattern blocks to teach geometric and spatial concepts.

22.Smith, K. MY LACE-UP BOOK. V. Nichols/Nickel Press. China. 1997. Develops spatial sense.

23. Corneille, B. GETTING MORE FROM MATH MANIPULATIVES: STRATEGIES, LESSONS, ACTIVITIES AND ASSESSMENT. Scholastic Inc. NY. 1995. Teacher resources for many math context standards.

24.Neuschwander, C. AMANDA BEAN'S AMAZING DREAM: A MATHEMATICAL STORY. Scholastic Inc. NY. 1998. Develops understanding of multiplication by using geometric shapes.

25.Paraquin, C. THE WORLD'S BEST OPTICAL ILLUSIONS. Scholastic Inc. NY. 1984. Develops spatial sense. 
Measurement

1. Myller, R. HOW BIG IS A FOOT? Bantam Doubleday Dell Books for Young Readers. 1990. Teaches measurement skills humorously.

2. Smith, K.B. LET'S MEASURE. V.Nichols/Nickel Press. China. 1997. Teaches measuring skills.

3. Keenan, S. THE BIGGEST FISH. Scholastic Inc. NY. 1996. Gives children firsthand experience in measuring in different ways.

4. FUN WITH FRUITS AND VEGETABLES: KID'S COOKBOOK. Dole Food Company. 1998. Gives children hands-on and practical experience with measuring quantities.

5. Carle, E. THE GROUCHY LADYBUG. HarperCollins Publishers. 1977. Illustrates time concepts.

6. Lovell, L. WHAT TIME IS IT? V. Nichols/Nickel Press. China. 1997. Very simple and clear directions on how to tell time.

7. Nagel, K. B. THE LUNCH LINE. Scholastic Inc. NY. 1996. Teaches about money.

8. THE COUNT YOUR CHANGE, WIPE-OFF BOOK. Scholastic Inc. NY. 1992. Develops money skills.

9. THE TIME WIPE-OFF BOOK. Scholastic Inc. NY. 1992. Hands-on experience telling time.

10.Hutchins, P. CLOCKS AND MORE CLOCKS. Aladdin Books. NY. 1970. Time-telling humorously taught.

11.Corneille, B. GETTING MORE FROM MATH MANIPULATIVES: STRATEGIES, LESSONS, ACTIVITIES AND ASSESSMENT. Scholastic Inc. NY. 1995. Teacher resource for many math content standards.

\section{Algebraic Thinking}

1. Murphy, S. READY, SET, HOP! HarperCollins Children's Books. NY. 1996. Teaches readers how to make equations.

2. PLANET DEXTER'S CALCULATOR MANIA! 101 WAYS TO ENJOY A CALCULATOR WITHOUT THROWING IT! Scholastic Inc. NY. 1995. Shows how to use a calculator while developing problem-solving skills.

3. Higdon, P. MATH MINDERS: FRACTIONS \& DECIMALS. GRADE 5. Frank Schaffer Publications, Inc. California. 1998. Shows how to use fractions and decimals in real-life situations for problem-solving.

4. Demi. ONE GRAIN OF RICE: A MATHEMATICAL FOLKLORE. Scholastic Inc. NY. 1997. Illustrates algebraic thinking.

5. Nagel, K.B. THE LUNCH LINE. Scholastic Inc. NY. 1996. Teaches children how to solve money problems.

6. Rocklin, J. THE CASE OF THE BACKYARD TREASURE. Scholastic Inc. NY. 1998. Teaches problem-solving in a fun, story format.

7. FUN WITH MONEY. V. Nichols/Nickel Press. China. 1997. Money skills and problem-solving.

Data Analysis and Probability

1. Shake, RATTle AND ROLL: COOL Things TO DO WiTH DICE. The Editors of Planet Dexter. Scholastic Inc. NY. 1995. Games to play with dice. Teaches probability concepts.

2. Hopping, L.J. \& Egan, C. SPORTS MATH MANIA! Sports Illustrated for Kids. 1996. Uses sports statistics to teach kids the value of math.

3. Murphy, S.J. BETCHA! Scholastic Inc. NY. 1997. Teaches estimation skills.

4. Barrett, J. CLOUDY WITH A CHANCE OF MEATBALLS. Scholastic Inc. NY. 1978. Teaches about probability with humor and silliness.

5. McGrath, B. MORE M \& M'S MATH. Charlesbridge Publishing, 1998. Illustrates concept of probability in a fun way. 